\title{
Anti-inflammatory and vasculogenic conditioning of peripheral blood mononuclear cells reinforces their therapeutic potential for radiation-injured salivary glands
}

\author{
Takashi I', Yoshinori Sumita ${ }^{2^{*}}$ (D), Takako Yoshida ${ }^{2}$, Ryo Honma ${ }^{1,2}$, Mayumi Iwatake ${ }^{2}$,
} Jorge Luis Montenegro Raudales ${ }^{2}$, Tomoko Shizuno ${ }^{3}$, Shinichiro Kuroshima ${ }^{4}$, Haruchika Masuda ${ }^{5}$, Makoto Seki ${ }^{3}$, Simon D. Tran' ${ }^{6}$, Takayuki Asahara ${ }^{4}$ and Izumi Asahina ${ }^{1}$

\begin{abstract}
Background: There are currently no effective treatments available for patients with irreversible loss of salivary gland (SG) function caused by radiation therapy for head and neck cancer. In this study, we have developed an effective culture method to enhance the anti-inflammatory and vasculogenic phenotypes of peripheral blood mononuclear cells (PBMNCs) and investigated whether such effectively conditioned PBMNCs (E-MNCs) could regenerate radiation-injured SGs and ameliorate salivary secretory function in mice.

Methods: Mouse PBMNCs were expanded in primary serum-free culture with five vasculogenic proteins for 5 days, and then the resulting cells (E-MNCs) were analyzed for their characteristics. Subsequently, $5 \times 10^{4} \mathrm{E}-\mathrm{MNCs}$ (labeled with EGFP in some experiments) were injected intra-glandularly into a mouse model of radiation-injured atrophic submandibular glands. After 2-3 weeks, the submandibular glands were harvested, and then the injected E-MNCs were tracked. Four, 8 , and 12 weeks after irradiation (IR), salivary outputs were measured to evaluate the recovery of secretory function, and the gland tissues were harvested for histological and gene expression analyses to clarify the effects of cell transplantation.
\end{abstract}

Results: The resulting E-MNCs contained an enriched population of definitive CD11b/CD206-positive (M2 macrophage-like) cells and showed anti-inflammatory and vasculogenic characteristics. Salivary secretory function in E-MNC-transplanted mice gradually recovered after 4 weeks post-irradiation (post-IR) and reached 3.8-fold higher than that of non-transplanted mice at 12 weeks. EGFP-expressing E-MNCs were detected in a portion of the vascular endothelium and perivascular gland tissues at 2 weeks post-IR, but mainly in some microvessels at 3 weeks. Between 4 and 12 weeks post-IR, mRNA expression and histological analyses revealed that E-MNC transplantation reduced the expression of inflammatory genes and increased the level of tissue-regenerative activities such as stem cell markers, cell proliferation, and blood vessel formation. At 12 weeks post-IR, the areas of acinar and ductal cells regenerated, and the glands had less fibrosis.

(Continued on next page)

\footnotetext{
* Correspondence: y-sumita@nagasaki-u.ac.jp

${ }^{2}$ Basic and Translational Research Center for Hard tissue Disease, Nagasaki

University Graduate School of Biomedical Sciences, 1-7-1 Sakamoto, Nagasaki

852-8588, Japan

Full list of author information is available at the end of the article
}

C The Author(s). 2019 Open Access This article is distributed under the terms of the Creative Commons Attribution 4.0 International License (http://creativecommons.org/licenses/by/4.0/), which permits unrestricted use, distribution, and reproduction in any medium, provided you give appropriate credit to the original author(s) and the source, provide a link to the Creative Commons license, and indicate if changes were made. The Creative Commons Public Domain Dedication waiver (http://creativecommons.org/publicdomain/zero/1.0/) applies to the data made available in this article, unless otherwise stated. 
(Continued from previous page)

Conclusions: This effective conditioning of PBMNCs is a simple, rapid, and efficient method that provides a noninvasive source of therapeutic cells for regenerating radiation-injured atrophic SGs.

Keywords: Radiogenic salivary gland dysfunction, Cell-based therapy, Peripheral blood mononuclear cells, Macrophage, Anti-inflammation, Vasculogenesis

\section{Background}

Many patients with head and neck cancer are treated with radiotherapy either alone or in combination with surgery and/or chemotherapy. After such treatment, although the patient's prognosis is improved, the radiogenic damage to the salivary glands (SGs) frequently causes severe salivary hypofunction. These patients suffer from severe xerostomia, dysphagia, dental caries, oropharyngeal infections, and oral mucositis $[1,2]$, and such complications lead to the reduction in quality of life [3]. To reduce radiation damage to SGs, approaches such as brachytherapy, intensity-modulated radiation therapy (IMRT), and heavy particle beam therapy have shown merit, but a significant proportion of patients still experience salivary hypofunction [4]. There are currently no adequate treatments for patients with such irreversible glandular damage. Therefore, developing an adequate treatment is urgently needed for the restoration of radiation-induced atrophic SGs.

For functional restoration of damaged SGs due to irradiation, various experimental approaches, such as the use of gene therapy, tissue engineering, and cell-based therapy, have been investigated [5-8]. In particular, cell-based therapies for atrophic SG using intra-glandular or intra-venous injections of SG stem/progenitor cells or mesenchymal stem cells (MSCs) have succeeded in slowing the atrophic process $[9,10]$. For instance, it has been shown that spheroid cultures of adult SG cells can enrich progenitor cells (salispheres) and that intra-glandular transplantation of salisphere-derived c-kit ${ }^{+}$-expressing cells partially restores the tissue morphology and organ function of radiationdamaged SGs [11]. Likewise, we have previously focused on bone marrow-derived cells (BMDCs) including MSCs and found that BMDCs or cultured MSCs can improve the function of damaged SGs in both irradiation and Sjögren's syndrome mouse models $[6,12]$. These cells display paracrine effects by releasing anti-inflammatory, vasculogenic, or anti-apoptotic cytokines such as IL-10, VEGF, bFGF, and HGF to damaged glands [13, 14]. These experimental approaches strongly suggest that cell-based therapies are promising as an alternative remedy. However, the cell sources reported to date such as SG, bone marrow, adipose, and dental pulp tissues $[6,9,11,15]$ require invasive procedures to harvest at the donor site, particularly for elderly patients. In addition, securing a sufficient number of highly functional stem/progenitor cells in culture to ensure their therapeutic effects remains a challenge.
Meanwhile, it has been demonstrated that autologous human $\mathrm{CD}_{34}^{+}$and $\mathrm{CD}^{+} 33^{+}$stem/progenitor cells in bone marrow (BM) or peripheral blood (PB) have therapeutic effects, including neovascularization in patients with severe ischemic diseases [16]. These stem/progenitor cells serve as an enriched source of endothelial progenitor cells (EPCs). It is well known that EPCs favor angiogenesis and vasculogenesis by their proliferation and differentiation abilities [16]. In fact, a cell-based therapy using EPCs strongly promotes the revascularization and restoration of numerous ischemic tissues, including the myocardium, brain, and skin [17-19]. This indicates that blood vessel formation and blood supply are essential for tissue regeneration. However, EPCenriched populations $\left(\mathrm{CD} 34^{+}, \mathrm{CD} 133^{+}, \mathrm{CD} 34^{+} /\right.$VEGFR-2 ${ }^{+}$, or $\mathrm{CD} 133^{+} /$VEGFR $-2^{+}$) are usually scarce even in BM and $\mathrm{PB}$, and they decline numerically and functionally in patients with aging or morbidity [20]. Therefore, to augment the qualitative and/or quantitative properties of such vasculogenic cell fractions, we have recently developed a novel culture method called "quality- and quantity-controlled culture (QQ-culture)” of BM-, PB-, and umbilical cord blood MNCs [21]. This serum-free QQ-culture system contains five recombinant proteins (stem cell factor, thrombopoietin, vascular endothelial growth factor, interleukin-6, and Flt-3 ligand) and can successfully enhance the vasculogenic potential of BMMNCs and PBMNCs in primary culture. Indeed, QQ-culture can reverse the diabetic vasculogenic dysfunction of BMMNCs and achieve the control levels of EPC function [22]. We have also shown the potential of cell-based therapy using human QQ-cultured PBMNCs for ischemic diseases [23]. These results have implications for the use of QQ-cultured PBMNCs to ameliorate ischemic salivary dysfunction, for which no adequate treatments are currently available. However, interestingly, QQ-culture of PBMNCs promotes not only the expansion of EPCs but also the adoption of regenerative phenotypes by macrophages and $\mathrm{T}$ lymphocytes [23]. In particular, the M2 phenotype of macrophage-like cells rather than EPCs appears at a specific period (5-7 days) of this primary culture. Therefore, we assumed that this specific QQ-culture condition (which we named "5G-culture") of PBMNCs may be extremely effective in promoting tissue regenerative activity with a phenotype transition between anti-inflammatory macrophages and $\mathrm{T}$ lymphocytes. It has been shown that paracrine effects by MSC therapy function via induction of the anti-inflammatory phenotype of activated macrophages 
at injured sites, and such macrophages contribute to neovascularization and subsequent tissue regeneration [24-26].

The aim of this study was to investigate whether effectively conditioned PBMNCs (effective PBMNCs; E-MNCs), resulting from the induction of M2 macrophages, could rescue radiation-induced SG hypofunction in mice by direct transplantation of cells into the submandibular glands. This study is a pre-requisite step for future clinical trials aimed at developing cell-based therapies for atrophic SGs. Although the mechanisms of regeneration are not currently well understood, we have previously found that autologous BMDC injections have beneficial therapeutic effects via the promotion of anti-inflammation and vasculogenesis in radiogenic-injured SGs or oral mucositis mouse models $[6,27]$. Therefore, the use of E-MNCs, which do not require a long cell expansion process, is a simple and direct approach using a readily available source of cells (blood) that can be obtained with low invasiveness.

\section{Methods}

\section{Animals}

C57BL/6JJcl mice (inbred strain) (CLEA Japan Inc., Tokyo, Japan) were employed as the recipient (female mice) and donors (male mice), and C57BL/6-Tg (CAG-EGFP) male mice (Japan SLC Inc., Shizuoka, Japan) were used in some experiments as donors. All mice were kept under clean conventional conditions at the Nagasaki University animal center. All experimental procedures were performed in accordance with the guidelines approved by the Nagasaki University Ethics Committee (1605271307 and 1610051411).

\section{Serum-free 5G-culture of PBMNCs}

Mouse PBMNCs were cultured under the 5G-culture condition, which is a modified human QQ-culture system as described in our previous work [23], specific conditions of which were established by CellAxia Inc. (Tokyo, Japan). Briefly, peripheral blood was obtained by collecting the blood from the hearts of donor mice, and the fraction containing PBMNCs was isolated by density gradient centrifugation using separating medium (Histopaque-1083; Sigma Aldrich, St. Louis, MO, USA). Then, the isolated PBMNCs were seeded on 6-well Primaria tissue culture plates (BD Biosciences, San Jose, CA, USA) at a density of $2 \times 10^{6}$ cells $/ 2 \mathrm{ml}$ of $5 \mathrm{G}$-culture medium per well, and cultured for 5 days in serum-free 5G-culture medium (Stemline II Hematopoietic Stem Cell Expansion Medium; Sigma Aldrich), which was supplemented with five mouse recombinant proteins (Table 1). After 5 days of culture, 5G-cultured cells (effectively conditioned PBMNCs; E-MNCs) were harvested for subsequent experiments. In order to track the donor cells post-transplantation, some E-MNCs were obtained from C57BL/6-Tg (CAG-EGFP) mice.
Table 1 Contents of 5G-culture medium

\begin{tabular}{lll}
\hline Contents & Company, catalog no. & $\begin{array}{l}\text { Final concentration } \\
(\mathrm{ng} / \mathrm{mL})\end{array}$ \\
\hline rm SCF & Peprotech, \#250-03 & 100 \\
rm flt-3 ligand & Peprotech, \#250-31 L & 100 \\
rm TPO & Peprotech, \#315-14 & 20 \\
rm VEGF & Peprotech, \#450-32 & 50 \\
rm IL-6 & Peprotech, \#216-16 & 20 \\
\hline
\end{tabular}

\section{Evaluation of the characteristics of E-MNCs: flow cytometry analysis}

Freshly isolated PBMNCs and E-MNCs were subjected to flow cytometry to detect the surface antigen positivity

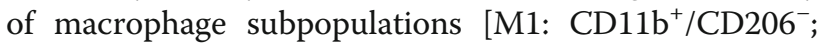

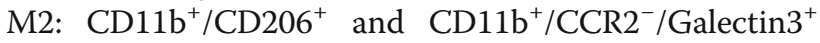
[28]], $\mathrm{T}$ lymphocytes $\left(\mathrm{CD}^{+}\right)$[Th1: $\mathrm{CXCR}^{+}$; Th2: $\mathrm{CXCR}^{+} / \mathrm{CXCR}^{-}$; Th17: $\mathrm{CXCR}^{+} / \mathrm{CXVR6}^{+}$in $\mathrm{CD}^{+} /$ $\mathrm{CD}^{+}{ }^{+} \mathrm{T}$ helper cells], B lymphocytes $\left(\mathrm{B}^{2} 20^{+}\right)$, and endothelial stem/progenitor cells $\left(\mathrm{c}-\mathrm{Kit}^{+} / \mathrm{Sca}-1^{+} /\right.$lineage $\left.{ }^{-}\right)$, along with the cell viability (propidium iodide (PI)). The Abs used are listed in Table 2. Cells were suspended in $2 \mathrm{mmol} / \mathrm{l}$ of ethylenediaminetetraacetic acid (EDTA/ $0.2 \%$ bovine serum albumin (BSA)/phosphate-buffered saline (PBS) buffer $\left(5 \times 10^{5}\right.$ cells $\left./ 200 \mu \mathrm{l}\right)$, were incubated after the addition of $10 \mu \mathrm{l}$ of FCR blocking reagent at $4{ }^{\circ} \mathrm{C}$ for $30 \mathrm{~min}$, and then equally dispensed into reaction tubes for subsequent staining $(100 \mu \mathrm{l} /$ tube). Each aliquot was incubated with $2 \mu \mathrm{l}$ of each 1 st-Ab at $4{ }^{\circ} \mathrm{C}$ for 20 min and then washed twice with $1 \mathrm{ml}$ of $2 \mathrm{mmol} / \mathrm{l}$ EDTA/0.2\% BSA/PBS buffer. Cells were resuspended in $2 \mathrm{mmol} / \mathrm{l}$ of EDTA/0.2\% BSA/PBS buffer $\left(2 \times 10^{5}\right.$ cells/ $200 \mu \mathrm{l})$. Flow cytometry analysis was performed using a LSRFortessa cell analyzer (BD Biosciences) and FlowJo software (Tomy Digital Biology Co., Ltd., Tokyo). The percent positivity of macrophage subpopulations and endothelial stem/progenitor cells per each gate in PBMNCs or E-MNCs was evaluated and then calculated in relation to that of the whole cell population.

\section{Evaluation of the characteristics of E-MNCs: anti- inflammatory and vasculogenic gene expressions}

Quantitative real-time PCR was used to determine the mRNA expressions of anti-inflammatory and vasculogenic (IL-1 $\beta$, IFN- $\gamma$, IL-10, VEGF-A, and B) genes in PBMNCs and E-MNCs; each was measured in triplicate. Total RNA was extracted with Trizol reagent (Invitrogen, Waltham, MA, USA), and first-strand complementary DNA synthesis was performed using SuperScript First-Strand Synthesis (Invitrogen). Complementary DNA was amplified with Takara-Taq (Takara Bio Inc., Shiga, Japan). PCR reactions were performed with an Mx3000P QPCR System (Agilent technology). Mouse-specific primer sets are shown in 
Table 2 Antibodies for flow cytometry

\begin{tabular}{|c|c|}
\hline Antibodies for flow cytometry & Company, catalog no. \\
\hline APC anti-mouse CD206 (MMR) & Biolegend, \#141707 \\
\hline APC rat lgG2a, $\mathrm{K}$ isotype Ctrl & Biolegend, \# 400511 \\
\hline APC-Cy7 anti-mouse/human CD11b & Biolegend, \#101225 \\
\hline APC/Cy7 anti-mouse CD4 & Biolegend, \#100413 \\
\hline APC/Cy7 rat lgG2b, k isotype Ctrl & Biolegend, \#400623 \\
\hline PE-Cy7 anti-mouse/human Mac-2 (Galectin-3) & Biolegend, \#125417 \\
\hline PE-Cy7 rat lgG2a, $\mathrm{K}$ isotype Ctrl & Biolegend, \#400521 \\
\hline APC anti-mouse CCR2-conjugate & $R \& D, \# F A B 5538 A$ \\
\hline APC rat lgG2b, k isotype Ctrl & Biolegend, \#400611 \\
\hline FITC anti-mouse/human CD45R/B220 & Biolegend, \#103205 \\
\hline FITC rat lgG2a, $\mathrm{k}$ isotype $\mathrm{Ctrl}$ & Biolegend, \#400505 \\
\hline PE anti-mouse CD3 & Biolegend, \#100205 \\
\hline PE rat lgG2b, $\mathrm{k}$ isotype $\mathrm{Ctrl}$ & Biolegend, \#400607 \\
\hline FITC anti-mouse CD183 (CXCR3) & Biolegend, \#126535 \\
\hline FITC Armenian hamster lgG, isotype Ctrl & Biolegend, \#400905 \\
\hline PE/Cy7 anti-mouse CD194 (CCR4) & Biolegend, \#131213 \\
\hline PE/Cy7 Armenian hamster lgG, isotype Ctrl & Biolegend, \#400921 \\
\hline APC anti-mouse CD196 (CCR6) & Biolegend, \#129813 \\
\hline APC Armenian hamster lgG, isotype Ctrl & Biolegend, \#400911 \\
\hline True-Stain Monocyte Blocker ${ }^{\mathrm{TM}}$ & Biolegend, \#426101 \\
\hline PE-Cy7 labeled mouse anti-mouse CD117 (c-Kit) & Biolegend, \#135111 \\
\hline PE-Cy7 rat lgG2b, K isotype Ctrl & Biolegend, \#400617 \\
\hline APC-Cy7 labeled mouse anti-mouse Ly-6A/E (Sca-1) & Biolegend, \#108125 \\
\hline APC-Cy7 rat lgG2b, k isotype Ctrl & Biolegend, \#400523 \\
\hline Lineage cocktail; biotin rat anti-mouse CD45R/B220 & $\mathrm{BD}, \# 553086$ \\
\hline Lineage cocktail; biotin rat anti-mouse TER-119/erythroid cells & $\mathrm{BD}, \# 553672$ \\
\hline Lineage cocktail; biotin Armenian hamster anti-mouse CD3e & $\mathrm{BD}, \# 553060$ \\
\hline Lineage cocktail; biotin rat anti-mouse CD11b antibody & BD, \#553309 \\
\hline Lineage cocktail; biotin rat anti-mouse Ly-6G/Ly-6c & $\mathrm{BD}, \# 553124$ \\
\hline Streptavidin-FITC conjugate & $\mathrm{BD}, \# 553141$ \\
\hline $\mathrm{Pl}$ & WAKO, \#169-26281 \\
\hline
\end{tabular}

Table 3. As an internal standard, glyceraldehyde-3phosphate dehydrogenase (gapdh) was used.

\section{Evaluation of characteristics of E-MNCs: EPC colony- forming assays}

To investigate the vasculogenic potential of PBMNCs (pre-5G-culture) and E-MNCs (post-5G-culture), the cells were seeded in 35-mm Primaria dishes (BD Biosciences) at $1 \times 10^{5}$ cells/dish (three dishes per culture), and then EPC colony-forming assays (EPC-CFA) were performed by using semisolid culture medium (MethoCult $\mathrm{SF}^{\mathrm{BIT}}$; STEMCELL Technologies, Inc., Vancouver, Canada) with pro-angiogenic growth factors/cytokines (Fig. 1, Table 4) as we previously reported [22]. Seven days after initiation of EPC-CFA, the number of adherent colonies per dish was assessed under a microscope, and the EPC colonyforming units (EPC-CFUs) were counted as previously described [21]. Simultaneously, to confirm the endothelial characteristics of colonized cells, we assessed the biochemical binding of isolectin B4-conjugated fluorescein isothiocyanate (ILB4-FITC) (Vector Laboratories, Burlingame, CA, USA), which is a marker of endothelial cells, and the uptake of acetylated low-density lipoprotein labeled with 1,1' -dioctadecyl-3,3,3',3' -tetramethylindo-carbocyanine perchlorate (AcLDL-DiI) (Biomedical Technologies, Inc., Stoughton, MA, USA), which is metabolized by a receptor-mediated process in endothelial cells, by fluorescence microscopy. 
Table 3 Mouse primer sets

\begin{tabular}{|c|c|c|}
\hline Gene & Forward primer & Reverse primer \\
\hline$i t-1 \beta$ & 5'-GCTGAAAGCTCTCCACCTCA-3' & 5'-AGGCCACAGGTATTTTGTCG-3' \\
\hline $11-10$ & 5'-GCTGGACAACATACTGCTAACC-3' & 5'-ATTTCCGATAAGGCTTGGCAA-3' \\
\hline$i f n-\gamma$ & 5'-ACAGCAAGGCGAAAAAGGATG-3' & 5'-TGGTGGACCACTCGGATGA-3' \\
\hline $\operatorname{tnf}-a$ & 5'-TACTTAGACTITGCGGAG-3' & 5'-AGAGTAAAGGGGTCAGAG-3' \\
\hline vegf-a & 5'-CCTCCGAAACCATGAACTTT-3' & 5'-TCATGGGACTTCTGCTCTCC-3' \\
\hline vegf-b & 5'-CTCATGATCCAGTACCCGAGC-3' & 5'-GCTTCACAGCACTCTCCTTT-3' \\
\hline vegf-c & 5'-CTCAATGCATGCCACGTGAG-3' & 5'-CAGCAACCCCCACATCTGTA-3' \\
\hline$f \mid t-1$ & 5'-CTCACTTGCACCGTGTATGG-3' & 5'-TGCTGGGATCCAGGATAAAG-3' \\
\hline flt-4 & 5'-GACGAGCTGGTGAAGCTACC-3' & 5'-TCACCTCTITGAGCACCAGA-3' \\
\hline$f \mid k-1$ & 5'-GCTTGCCTTATGATGCCAGC-3' & 5'-TCCAAAAGCGTCTGCCTCAA-3' \\
\hline Aqp5 & 5'-CCTTATCCATTGGCTTGTCG-3 & 5'-CCCAGAAGACCCAGTGAGAG-3 \\
\hline gapdh & 5'-TGCACCACCAACTGCTTAG-3' & 5'-GGATGCAGGGATGATGTTC-3' \\
\hline
\end{tabular}

Irradiation (IR) of mice and transplantation of E-MNCs

C57BL/6 mice were anesthetized with $10 \mu \mathrm{l} / \mathrm{g}$ body of ketamine $(10 \mathrm{mg} / \mathrm{ml})$ given by intraperitoneal (ip) injection and restrained in a container for irradiation. The submandibular glands were damaged by exposing them to a single dose of $12-$ Gy using gamma rays from PS3100SB (Pony Industry Co, Ltd., Osaka, Japan). The radiation was collimated to the head and neck area to guarantee less than $10 \%$ beam strength in the rest of the body. Then, E-MNCs $\left(5 \times 10^{4}\right.$ cells per gland, a total of $1 \times 10^{5}$ cells) were directly injected into the submandibular glands at 3 days post-IR (Fig. 1). For transplantation, mice were randomly divided into four groups in a blinded fashion: (1) non-irradiation and non-cell transplantation [control group; $n=5$ for each time point, sacrificed at $1,2,3,4,8$, and 12 weeks after IR), total $n=30]$, (2) irradiation and injection of $20 \mu \mathrm{l}$ IMDM (Iscove's modified Dulbecco's media; Sigma Aldrich) without cell transplantation [sham group as an experimental control; $n=5$ at each time point $(4,8$, and 12 weeks after IR), total $n=15]$, (3) irradiation and transplantation of E-MNCs with $20 \mu \mathrm{l}$ IMDM [E-MNC group; $n=5$ at each time point $(2,3,4,8$, and 12 weeks after IR), total $n=25]$, and (4) irradiation and transplantation of PBMNCs with $20 \mu \mathrm{l}$ IMDM [PBMNC group; $n=5$ at each time points $(4,8$, and 12 weeks after IR), total $n=15]$.

\section{Salivary flow rate and gross appearance of SGs}

To measure the secretory function (salivary flow rate (SFR)) of SGs, mice were kept under general anesthesia by ip injection of $10 \mu \mathrm{l} / \mathrm{g}$ body weight of ketamine. Whole saliva was collected after stimulation of secretion

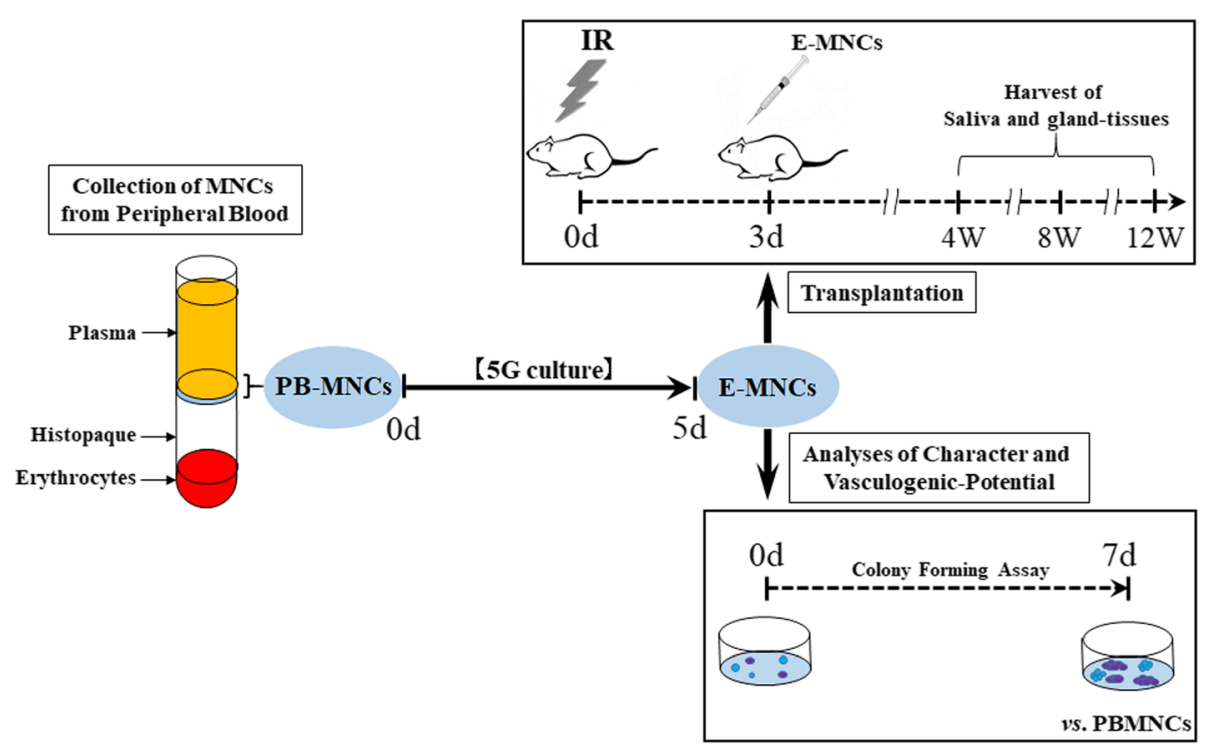

Fig. 1 Schematic diagram describing the experimental design for E-MNC-based therapy of radiogenic-injured salivary glands 
Table 4 Contents in semisolid culture for EPC-CFA

\begin{tabular}{lll}
\hline Contents & Company, catalog no. & $\begin{array}{l}\text { Final } \\
\text { concentration }\end{array}$ \\
\hline rm VEGF & Peprotech, \#450-32 & $50 \mathrm{ng} / \mathrm{mL}$ \\
rm basic FGF & Peprotech, \#450-33 & $50 \mathrm{ng} / \mathrm{mL}$ \\
rm EGF & Peprotech, \#315-09 & $50 \mathrm{ng} / \mathrm{mL}$ \\
rm IGF-1 & Peprotech, \#250-19 & $50 \mathrm{ng} / \mathrm{mL}$ \\
rm SCF & Peprotech, \#250-03 & $100 \mathrm{ng} / \mathrm{mL}$ \\
rm IL-3 & Peprotech, \#213-13 & $20 \mathrm{ng} / \mathrm{mL}$ \\
Heparin & YOSHINDO, \#121-154 & $2 \mathrm{U} / \mathrm{mL}$ \\
FBS & SAFC Biosciences, \#12303 & $30 \%$ \\
\hline
\end{tabular}

by $0.5 \mathrm{mg} / \mathrm{kg}$ body weight pilocarpine (Sigma Aldrich) administered subcutaneously. Saliva was obtained from the oral cavity by a micropipette and placed into preweighed $1.5-\mathrm{ml}$ microcentrifuge tubes. It was collected for a 10-min period and its volume determined gravimetrically. SFR was determined at weeks $0,4,8$, and 12 post-IR, $n=5$ /group at each time point. At 2, 3, 4, 8, and 12 weeks after IR, the mice were sacrificed, and their submandibular glands were harvested. At that time, the body weights and the weights of submandibular glands were measured, and the gross appearance of harvested submandibular glands was observed before fixation, $n=$ 5/group at each time point.

\section{Detection of transplanted E-MNCs}

To track EGFP-expressing E-MNCs, the expression of green fluorescence in frozen sections was observed at weeks 2 and 3 post-IR in control and E-MNC groups. The blood vessels were stained by intravenous injection with ILB4-DyLight 594 (red) (Vector Laboratories) just before sacrificing. Fivemicrometer sections were fixed in $4 \%$ paraformaldehyde (PFA), rinsed by $0.01 \mathrm{~mol} / \mathrm{l} \mathrm{PBS}$, and the nuclei were counterstained with 4',6-diamidino-2'-phenylindole (DAPI; Vector Laboratories, Burlingame, CA, USA). Then, they were examined by a confocal laser microscope (LSM 800 with Airyscan; Carl Zeiss, Inc., Oberkochen, Germany) at $\times 200$ and $\times 400$ magnification, $n=5 /$ group at each time point. Additionally, two examiners independently counted the number of EGFP-expressing cells in the parenchyma and microvessels separately in a blinded manner under $\times 200$ magnification, five different fields per specimen/five sections, $n=5 /$ group at 2 and 3 weeks post-IR.

\section{Histological and immunohistological observations}

The harvested submandibular glands were fixed in $4 \%$ PFA and embedded in paraffin. Five-micrometer sections were stained with hematoxylin and eosin $(\mathrm{H} \& \mathrm{E})$ and examined microscopically under $\times 200$ magnification, $n=$ $5 /$ group at each time point.
For Masson's trichrome staining (Masson's Trichrome Stain Kit; Agilent Technology, Santa Clara, CA, USA) after deparaffinization and hydration, staining was performed with Weigert's iron hematoxylin solution and Biebrich scarlet-acid fuchsin. After that, tissues were stained with phosphotungstic/phosphomolybdic acid solution, aniline blue solution, and $1 \%$ acetic acid. Fibrosis was assessed by light microscopy under $\times 40$ magnification via five random fields in a section for five sections/ specimen. The percentage of fibrosis area was analyzed by ImageJ software (National Institutes of Health, Bethesda, MD, USA), $n=5$ /group at 12 weeks post-IR.

Furthermore, for periodic acid-Schiff (PAS) staining, tissue sections were analyzed using a PAS Kit (Sigma Aldrich). After deparaffinization and hydration, staining was performed with periodic acid solution and Schiffs reagent. Then, sections were counterstained with hematoxylin solution. The percentage of surface area occupied by acinar cells was assessed by light microscopy under $\times 100$ magnification and analyzed by Image software via three different fields in a section/five sections, $n=5$ /group at 12 weeks post-IR.

Immunohistological staining was performed with rat anti-mouse SCFR/c-Kit/CD117 antibody (1:50; R\&D Systems, Minneapolis, MN, USA), rabbit anti-mouse Sca-1/ Ly6 antibody (1:50; Abcam, Cambridge, UK), rabbit antimouse CD31 antibody (1:50; Abcam), mouse anti-mouse pan-cytokeratin antibody (1:100; Abcam), and goat antimouse NKCC1 antibody (1:100; Santa Cruz Biotechnology, Santa Cruz, CA, USA). The slides were then incubated with Alexa Fluor 546-conjugated goat anti-rabbit antibody (1: 100; Thermo Fisher Scientific Life Sciences, Waltham, MA, USA) for Sca-1 and CD31, FITC-conjugated donkey antirat antibody (1:100; Abcam) for c-Kit, TRITC-conjugated donkey anti-goat antibody (1:200; Abcam) for NKCC1, and FITC-conjugated donkey anti-mouse antibody (1:100; Abcam) for cytokeratin as secondary antibodies and counterstained with mounting medium for fluorescence with DAPI (Vector Laboratories). Sca-1/c-Kit, CD31/cytokeratin, and $\mathrm{NKCC1}$ were examined by a fluorescence microscope under $\times 200$ magnification. Then, two examiners independently counted the number of c-Kit/Sca-1-positive cells in a blinded manner via three different fields in a specimen/five sections, $n=5 /$ group at 4 weeks post-IR. For the assessment of the blood vessels and ducts, the percentage of surface area occupied by the blood vessels (stained by CD31) or ducts (stained by cytokeratin) was analyzed by ImageJ software via three different fields in a specimen/five sections, $n=5$ /group at 4,8 , and 12 weeks post-IR.

For PCNA, tissues were stained with rat anti-mouse PCNA antibody (1:1000; Abcam) and the VECTASTAIN $\mathrm{ABC}$ Kit (Vector Laboratories). After that, they were counterstained with hematoxylin. Tissues were examined by a light microscope under $\times 200$ magnification. Then, two examiners independently counted the number 
of positive cells in a blinded manner via three different fields in a specimen/five sections, $n=5 /$ group at 4 weeks post-IR.

\section{Inflammatory, vasculogenic, and saliva production gene expressions}

Quantitative real-time PCR was used to determine the mRNA expressions of inflammatory (IL- $1 \beta$, IFN- $\gamma$, and TNF- $\alpha$ ), vasculogenic (VEGF-A, VEGF-B, VEGF-C, Flt1, Flt-4, and Flk-1), and saliva production (AQP5) genes in the submandibular glands, $n=3$ /group at 4 and 8 weeks post-IR. Total RNA was extracted with Trizol reagent, and first-strand complementary DNA synthesis was performed by SuperScript First-Strand Synthesis. Complementary DNA was amplified with Takara-Taq. PCR reactions were performed with an Mx3000P QPCR System. Mouse-specific primer sets are shown in Table 3. As an internal standard, glyceraldehyde-3-phosphate dehydrogenase (gapdh) was used.

\section{Epidermal growth factor (EGF) concentration}

Concentration of EGF in saliva $(n=4 /$ group in sham and E-MNC groups at week 8 post-irradiation) was measured by ELISA method (Abcam). This assay employed a quantitative sandwich enzyme immunoassay technique. The intensity of the color measured is in proportional to the amount of EGF. The sample values were compared to the EGF standard curve.

\section{Statistical analysis}

Means were analyzed via one-way analysis of variance. The Dunnett multiple comparison $t$ test was used to detect any significant differences within each group. Experimental values are presented as means \pm SD; $p<0.05$ was considered statistically significant.

\section{Results}

\section{Characteristic changes in anti-inflammatory and} vasculogenic potential of MNCs after 5G-culture

At 5 days of culture, some adherent cells became larger and changed their morphology to macrophage-like round shapes (Fig. 2a). Then, flow cytometry revealed that an M2 macrophage-enriched fraction $\left(\mathrm{CD} 11 \mathrm{~b}^{+} /\right.$ $\mathrm{CD}^{206^{+}}$) distinctly appeared in E-MNCs at this time (from 1.07 to 5.51\%) (Fig. 2b, c). Furthermore, CCR2 ${ }^{-}$/ Galectin $^{+}$cells (as M2 macrophages) in the CD11bpositive cell fraction obviously increased (from 3.08 to 57.1\%) after 5G-culture (Additional file 1a). In contrast,

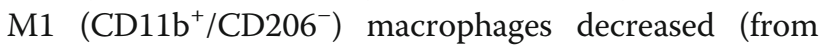
14.17 to $7.71 \%$ ), and the M1/M2 ratio in E-MNCs markedly decreased compared with that in PBMNCs (M1/ M2; from 13.14 to 1.55) (Fig. 2c). Meanwhile, many cells in E-MNCs were also characterized by an increased fraction of CD3-positive $\mathrm{T}$ lymphocytes (Fig. 2b), and
$\mathrm{CXCR}^{+} / \mathrm{CXCR}^{-}$cells (as Th2 cells) proliferated from approximately 0.1 to $20 \%$ in $\mathrm{CD}^{+} / \mathrm{CD}^{+} \mathrm{T}$ lymphocytes (Additional file 1b). However, there was no change in the cell number of Th1 and Th17 cells during 5G-culture $\left(\mathrm{CXCR}^{+} / \mathrm{CD}^{+} / \mathrm{CD}^{+}\right.$cells and CXCR $4^{+} / \mathrm{CXCR}^{+} / \mathrm{CD}^{+} /$ $\mathrm{CD}^{+}$cells, respectively) (Additional file $1 \mathrm{~b}$ ). Consistent with this phenomenon, the inhibited mRNA expression of inflammatory genes (IL-1 $\beta$ and IFN- $\gamma$ ) and the upregulated expression of anti-inflammatory and vasculogenic genes (IL-10 and VEGF-A) were clearly seen (Fig. 2d). Additionally, when we evaluated the existence of a functional EPC fraction in E-MNCs, the number of EPC colonies derived from E-MNCs remarkably increased at day 7 after the plating of MNCs for EPC-CFA (Fig. 2e). These colonies were positive for ILB4-FITC (ILB4; binds to endothelial cells) and AcLDL-DiI (AcLDL; labels endothelial cells) (Additional file 1c), and endothelial stem/progenitor cells $\left(\mathrm{c}-\mathrm{Kit}^{+} / \mathrm{Sca}-1^{+} /\right.$lineage $\left.{ }^{-}\right)$certainly increased by 5 G-culture, though they were fairly few in number (approximately $2.5 \%$ ) compared to other fractions such as macrophages or $\mathrm{T}$ lymphocytes (Additional file 1d). These phenomena strongly suggested that E-MNCs had acquired anti-inflammatory and vasculogenic characteristics during 5G-culture.

\section{Macroscopic observations after transplantation}

Overall, saliva secretions were increased in E-MNCtransplanted mice at weeks $4,8\left({ }^{*} p<0.05\right)$, and $12(* * p<$ $0.01)$ post-IR when compared to non-transplanted mice, and they gradually recovered after 4 weeks post-IR (Fig. 3a). Meanwhile, SFR in non- or PBMNCtransplanted mice was reduced severely after 4 weeks (Fig. 3a, Additional file 2a). In gross appearance, the size of submandibular glands harvested from E-MNCtransplanted mice was larger, and their appearance seemed to be usual when compared with those from non-treated mice at 12 weeks after IR (Fig. 3b). At 12 weeks after IR, the weights of the submandibular glands in E-MNC-treated mice had recovered when compared with those in non-treated mice (Fig. 3c; ${ }^{*} p<0.05$ ). Although the body weights of mice increased gradually, here was no statistically significant difference between the groups (Fig. 3d).

\section{Detection of donor cells in the submandibular glands}

At 2 weeks post-IR, some microvascular endothelial cells stained by ILB4-DyLight 594 (red) expressed EGFP (EMNCs; green), and scattered EGFP-expressing cells were also seen at the perivascular parenchyma of gland tissues in E-MNC-transplanted mice (Fig. 4a, b). However, EGFP-expressing cells could be detected only in some microvessels and were absent in the parenchyma of EMNC-transplanted submandibular glands at 3 weeks post-IR (Fig. 4c-e). Quantitative analysis revealed that 


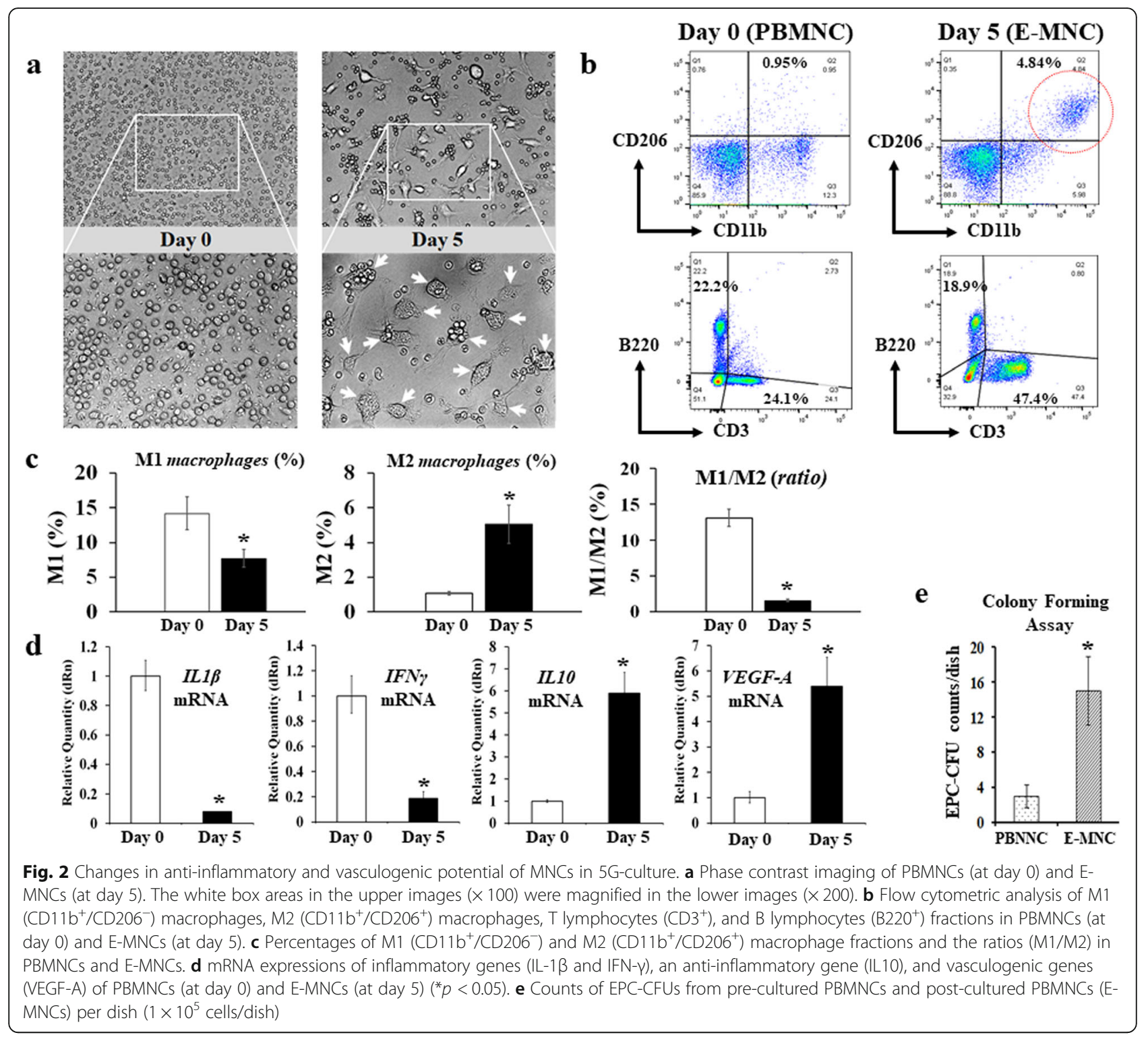

some EGFP-expressing cells were observed among microvascular endothelial cells (about 18 cells/field) and in the perivascular parenchyma (about 24 cells/field) of gland tissues in E-MNC-transplanted mice at 2 weeks after IR (Fig. 4f). However, EGFP-expressing cells could be detected only in some microvessels (about 36 cells/ field) and scarcely in the parenchyma (about 3 cells/ field) at 3 weeks (Fig. 4g).

Gene expressions and histological observations related to tissue regenerative activity from 4 to 12 weeks post-IR At 4 weeks after IR, due to irradiation, mRNA expressions of inflammatory (IL- $1 \beta$, IFN- $\gamma$, and TNF- $\alpha$ ) genes in the submandibular glands of non- and E-MNCtransplanted mice were significantly upregulated when compared with those in the control group (Fig. 5a).
However, the mRNA expressions in E-MNCtransplanted mice were significantly downregulated when compared with non-transplanted mice (IL-1 $\beta$ and INF- $\gamma,{ }^{* * *} p<0.01$; TNF- $\left.\alpha,{ }^{*} p<0.05\right)$. The upregulation of vasculogenic (VEGF-A, VEGF-B, and VEGF-C) gene expressions was seen in the submandibular glands of EMNC-transplanted mice when compared with nontransplanted mice (VEGF-B, ${ }^{*} p<0.05$; VEGF-C, $* * p<$ 0.01) (Fig. 5a). The expressions of VEGF-A, VEGF-B, and VEGF-C in E-MNC-treated mice were upregulated by 1.9-, 7.8-, and 2.1-fold, respectively. Consistent with these results, the expression levels of Flt-1 (VEGFR-1) and Flt-4 (VEGFR-3) genes were significantly higher (Flt-1, 2.3-fold; Flt-4, 2.5-fold) in treated mice when compared with non-treated mice (Flt-1, ${ }^{*} p<0.05$; Flt-4, $* p<0.05$ ) (Additional file 2b). Meanwhile, there was no 
$\mathbf{a}$

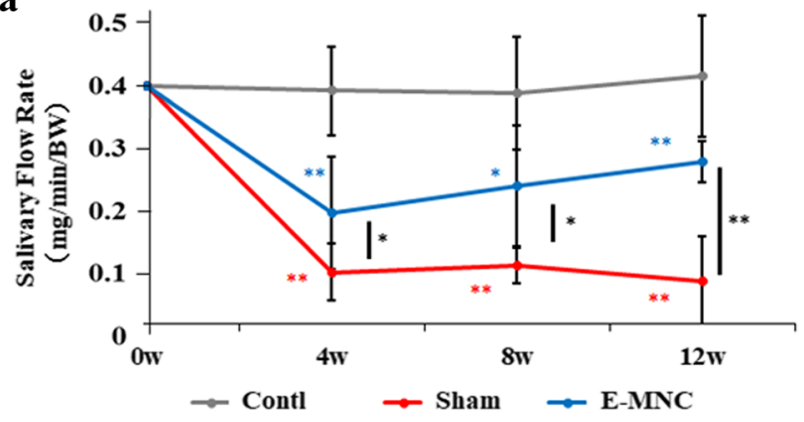

c

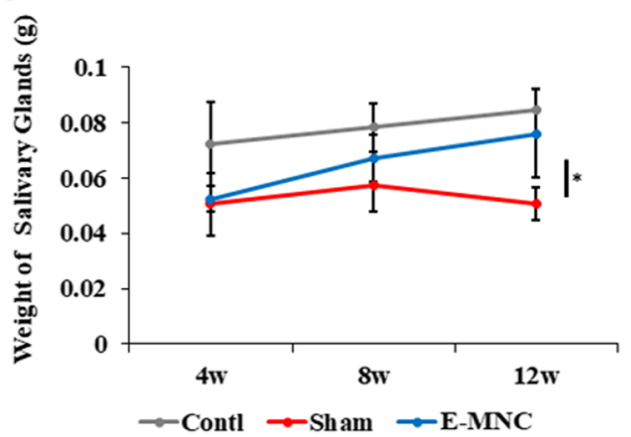

b

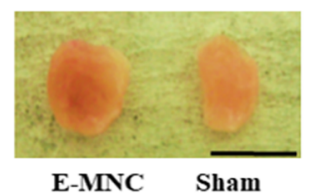

d

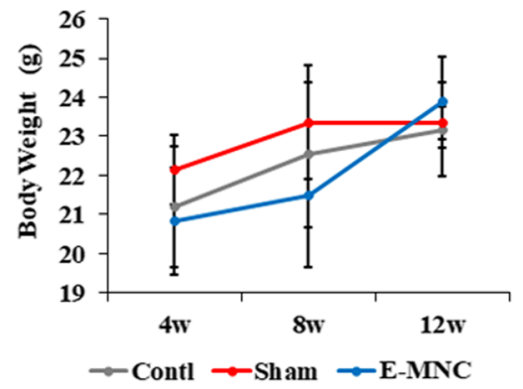

Fig. 3 Macroscopic findings after IR and cell transplantation. a Changes of salivary flow rate (SFR) at 0, 4, 8, and 12 weeks after IR. b Gross appearance of harvested submandibular glands of the E-MNC group (EMNC-treated mice) and sham group (non-treated mice) at 12 weeks after IR (scale bar, $5 \mathrm{~mm}$ ). c Weight changes of both submandibular glands at 4, 8, and 12 weeks after IR. $\mathbf{d}$ Changes of body weight at 4, 8, and 12 weeks after IR. The blue asterisk represents statistical significance between the control and E-MNC groups $\left(*^{*} p<0.01,{ }^{*} p<0.05\right)$. The red asterisk represents statistical significance between the control and sham groups $\left({ }^{* *} p<0.01,{ }^{*} p<0.05\right)$. The black asterisk represents statistical significance between the sham and E-MNC groups ( ${ }^{* *} p<0.01,{ }^{*} p<0.05$ )

significant difference among the groups with regard to flk-1 (VEGFR-2) mRNA expression (Additional file 2b). As for histological observations, c-Kit and Sca-1 (markers for salivary progenitor cells) were prominently expressed in ductal cells of E-MNC-treated mice (Fig. 5b). The number of double-positive cells in EMNC-transplanted mice was significantly larger than those of the control $(* * p<0.01)$ and non-transplanted mice $\left.{ }^{* * *} p<0.01\right)$ (Fig. 5 c). Brown-stained PCNA-positive cells were identified in acinar cells (box area in E-MNC specimen) of the submandibular glands in all groups (Fig. 5d), but the number of positive cells for PCNA was larger in E-MNC-treated mice than in control $(" p<0.05)$ and non-transplanted mice $\left.{ }^{* * *} p<0.01\right)$ (Fig. 5e). CD31 staining showed that irradiation remarkably decreased the blood vessels in the submandibular glands of nontreated mice until 12 weeks (Fig. 5f). Only the narrow and feeble blood vessels were detected in non-treated mice. In contrast, the areas of the blood vessels in EMNC-treated mice were initially reduced by 4 weeks post-IR, but those areas gradually recovered by 12 weeks (Fig. 5g). At 12 weeks post-IR, the blood vessels in EMNC-transplanted mice seemed to have been reconstructed markedly (Fig. 5f, g). Furthermore, regarding the saliva composition, the concentration of EGF, which plays an important physiological role in the maintenance of SG and oral mucosal tissues, in the saliva secreted from E-MNC-treated mice was markedly elevated when compared to that of non-transplanted mice $(" p<0.05)$ (Additional file $3 \mathrm{a}$ ). This finding suggests the tissue regenerative activity was surely accelerated in E-MNCtreated SGs.

\section{Histological observations at 12 weeks post-IR}

At 12 weeks after IR, vanishing and vacuolar degeneration in the acinar cell area was seen in irradiated submandibular glands, particularly in non-transplanted mice (Fig. 6a). Furthermore, a remarkable fibrosis area was found in non-treated mice (Fig. 6a, b). However, the fibrosis in E-MNC-transplanted mice was visibly suppressed when compared to non-treated mice (Fig. 6b, e; $" p<0.05)$. Meanwhile, acinar cells decreased by irradiation in non-transplanted mice and E-MNC-treated mice, but PAS staining revealed that an approximately 1.8-fold larger area of acinar cells was preserved in EMNC-treated mice compared to non-treated mice (Fig. 6c, f; ${ }^{* *} p<0.01$ ). Furthermore, the expression of NKCC1 (a marker of salivary acinar cells) in treated 


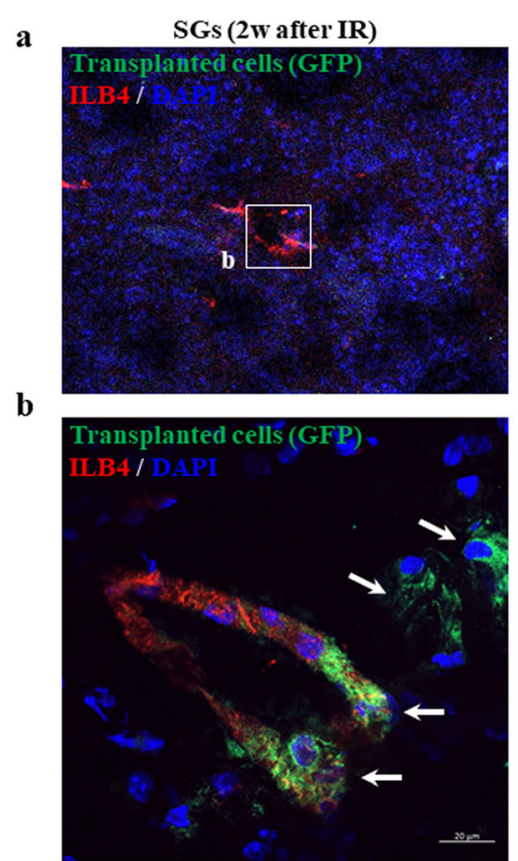

c

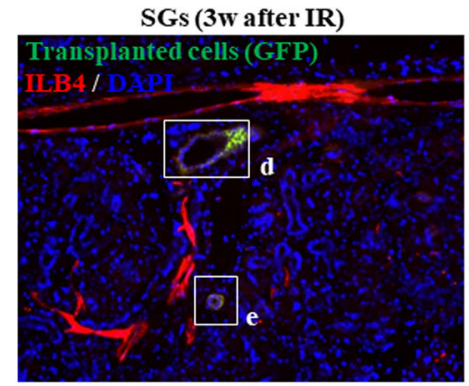

d
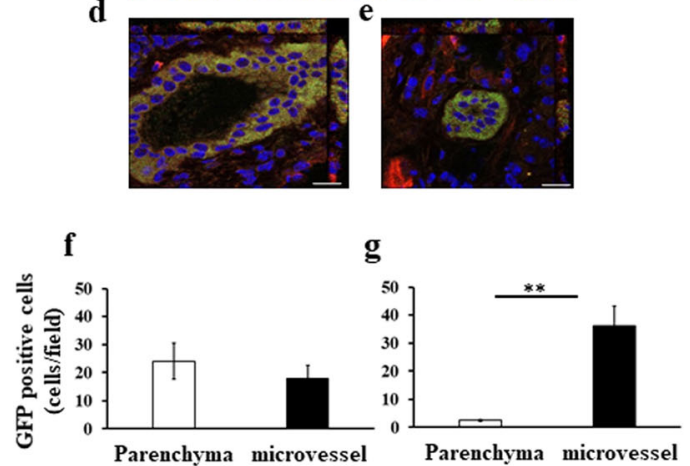

Fig. 4 Detection of transplanted E-MNCs. a At 2 weeks after IR, GFP-expressing cells were detected in the microvessels and parenchyma $(\times 200)$ in the submandibular glands. The blood vessels were stained by ILB4. b The white box area in a was magnified (scale bar, $20 \mu \mathrm{m})(\times 400)$. At 2 weeks, GFP-expressing cells (white arrow) were recognized clearly in vascular epithelia and parenchyma at the periphery of blood cells in the submandibular glands. Green, transplanted GFP-positive E-MNCs; red, blood vessels stained by ILB4; blue, DAPI. c At 3 weeks, they were detected only in the microvessels (scale bar, $200 \mu \mathrm{m})(\times 200)$. d, e The white box areas in c were magnified (scale bar, $20 \mu \mathrm{m})(\times 400)$. Green, transplanted GFP-positive E-MNCs; red, blood vessels stained by ILB4; blue, DAPI. $\mathbf{f}, \mathbf{g}$ The graphs show the number of observed EGFP-expressing cells ( $\times 200$ ) in microvascular endothelium and perivascular parenchyma of gland tissues in E-MNC-transplanted mice at 2 weeks post-IR (f) and at 3 weeks post-IR (g)

mice seemed to be the same level as in the control, but the level in non-treated mice was extremely low (Fig. 6d). This result was consistent with that of the PAS staining. Finally, the areas of ductal cells (stained by cytokeratin as shown in Fig. 5f) in the submandibular glands of nontreated mice were narrow (Fig. 6g). However, the percentage area in E-MNC-treated mice recovered to the same level as in control mice (Fig. 6g). Consistent with these observations, the expression level of AQP5 gene, which plays a role in the generation of saliva in SGs, was recovered in E-MNC-treated mice $\left({ }^{* *} p<0.01, " p<0.05\right)$ (Additional file $3 \mathrm{~b}$ ). This result suggests E-MNC injection ameliorates not only tissue reconstruction but also the saliva secretory function at this stage.

\section{Discussion}

In this study, we demonstrated that a cell therapy approach based on E-MNCs has therapeutic effects on radiogenic salivary hypofunction. The positive study outcomes were as follows: (1) treatment by E-MNCs, obtained from the peripheral blood, reliably recovered saliva secretion; (2) E-MNCs clearly promoted tissue regenerative activities in the atrophic glands via their antiinflammation and vascularization actions as explants; and
(3) E-MNCs might have affected these phenomena in a paracrine manner and/or by their vascular differentiation. These outcomes indicated that this strategy could be a promising option for developing future treatments.

As for the recovery of dysfunction, saliva secretion in the treated mice (E-MNC group) was reduced up to 4 weeks as with non-treated mice (IR group) (a 50\% reduction in normal control mice), but less reduction was shown in treated mice when compared with non-treated mice (a $77 \%$ reduction). Then, saliva production gradually recovered in treated mice to a level of $35 \%$ less than that of normal mice at 12 weeks. In contrast, the reduction rate in non-treated mice (77-82\% reduction) did not change during the evaluation period of this study. Consistent with this result, the submandibular glands in treated mice regained their weight to the level of those in normal mice at 12 weeks, but the weights were significantly less in non-treated mice. In addition, EGF concentration in the saliva secreted from the treated mice was elevated 3.2-fold higher than that from non-treated mice at 8 weeks. These phenomena definitely indicated that E-MNCs had a certain therapeutic effect in reducing radiogenic damage and/or restoring the secretory function of atrophic glands. Recently, proposed 


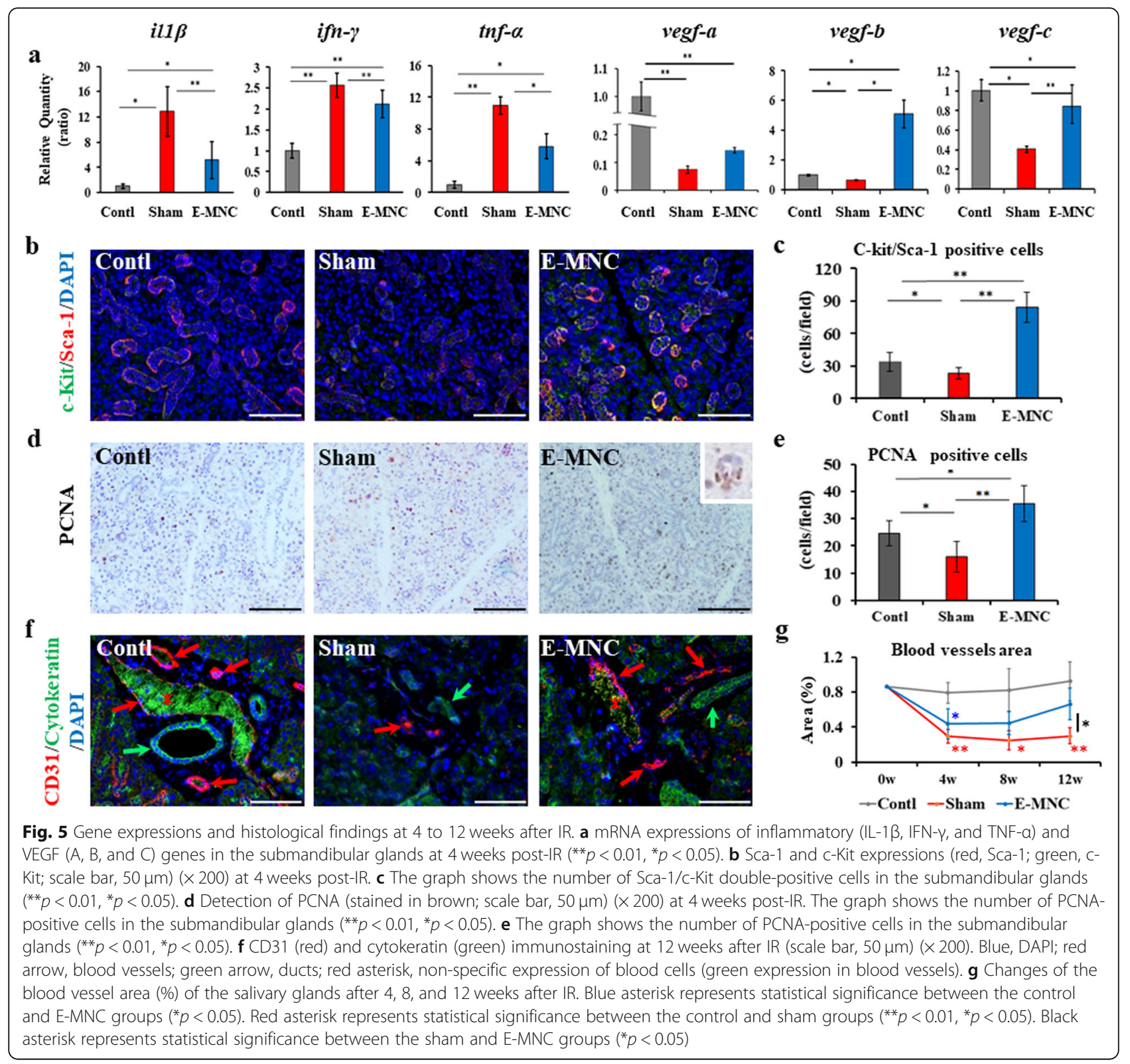

experimental approaches using SG stem cells, BMDCs, and MSCs have shown their ability to functionally restore SGs injured by irradiation $[6,9,11]$. However, as mentioned above, their actual availability is thought to be limited, because these autologous cells can only be harvested in a limited number from donor tissues. Furthermore, to obtain a sufficient number of capable stem cells, an expansion process is required in vitro, but the reality is that somatic stem cells such as MSCs lose their plasticity significantly during cell expansion and passaging, in particular depending on the patient's age and morbidity [29-31]. The present study revealed that EMNCs can rescue the dysfunction with high efficacy with a smaller number of transplanted cells $\left(5 \times 10^{4} /\right.$ gland). This outcome led us to believe that cell therapies using E-MNCs will be promising for future clinical applications because the peripheral blood is a readily accessible cell source that can be harvested with minimal invasiveness in elderly patients. Moreover, E-MNCs may contribute the functional restoration of atrophic glands more directly than BMDCs or MSCs, because exogenous MSCs can affect tissue regeneration by eliciting the polarization of macrophages toward an antiinflammatory M2 phenotype, which produce large amounts of IL-10 [32, 33]. Indeed, E-MNCs can be expanded in primary culture, and the most significant advantage is that this functional primary culture system enhances the EPC fraction and elicits the regenerative 


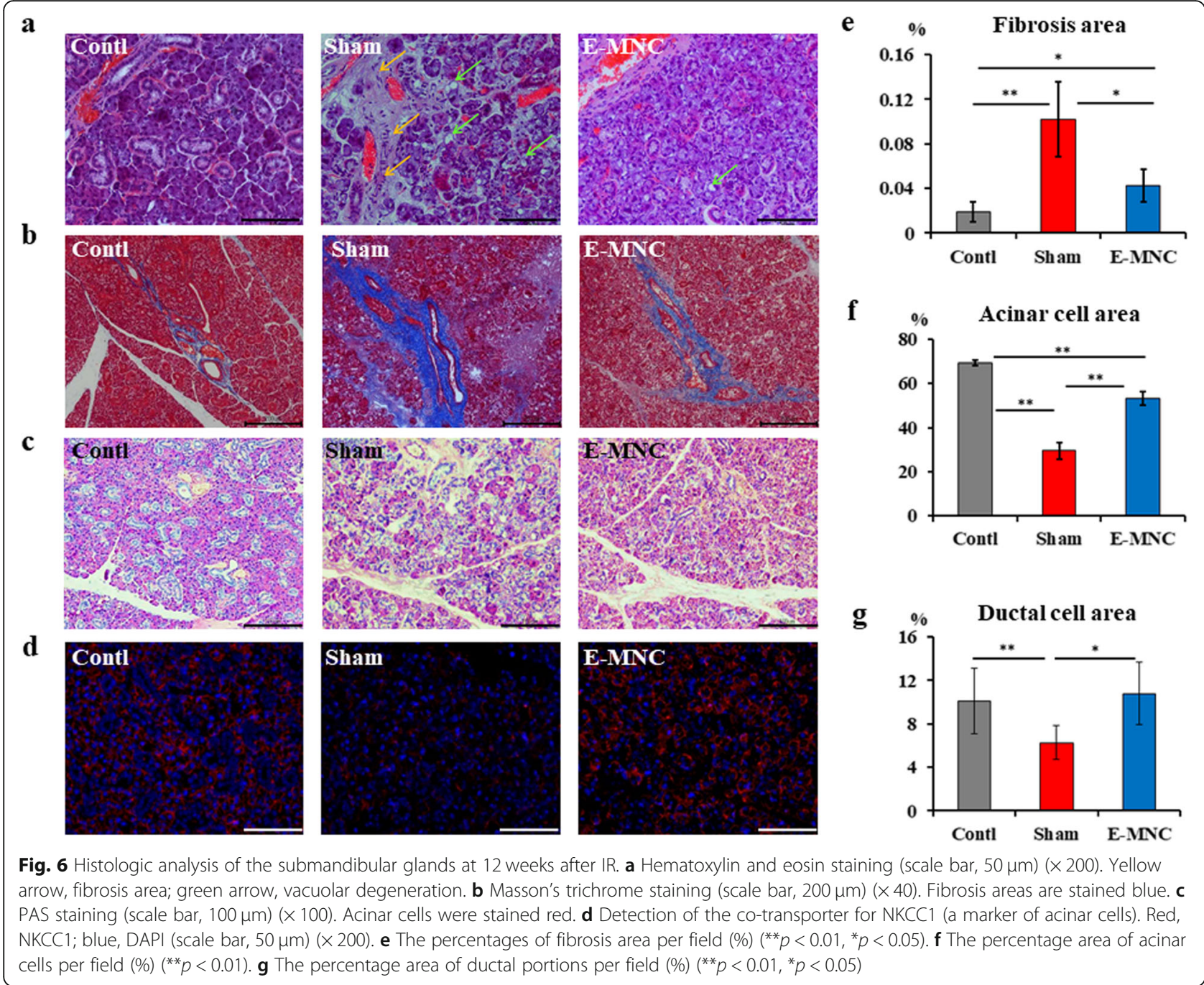

phenotype of macrophages and $\mathrm{T}$ lymphocytes from PBMNCs. In this study, mouse PBMNCs were composed of approximately $46 \%$ lymphocytes $\left(24 \% \mathrm{CD}^{+} \mathrm{T}\right.$ lymphocytes and $22 \% \mathrm{~B} 220^{+}$B lymphocytes), approximately $15 \%$ monocytes/macrophages $\left(14 \% \mathrm{CD} 11 \mathrm{~b}^{+} / \mathrm{CD} 206^{-} \mathrm{M} 1\right.$

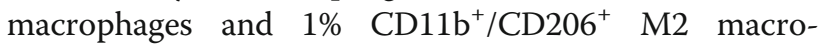
phages), and approximately $0.02 \%$ endothelial stem/progenitor cells $\left(\mathrm{c}-\mathrm{Kit}^{+} / \mathrm{Sca}^{-} 1^{+} /\right.$lineage $\left.^{-}\right)$. However, after $5 \mathrm{G}-$ culture, E-MNCs were comprised of approximately $66 \%$ lymphocytes $\left(47 \% \mathrm{CD}^{+} \mathrm{T}\right.$ lymphocytes and $19 \% \mathrm{~B}^{+} 20^{+} \mathrm{B}$ lymphocytes), approximately $13 \%$ monocytes/macrophages (7\% $\mathrm{CD} 11 \mathrm{~b}^{+} / \mathrm{CD}^{206^{-}} \mathrm{M} 1$ macrophages and $6 \% \mathrm{CD}^{2} \mathrm{~b}^{+}$/ $\mathrm{CD}^{206^{+}} \mathrm{M} 2$ macrophages), and approximately $2.5 \%$ endothelial stem/progenitor cells $\left(\mathrm{c}-\mathrm{Kit}^{+} / \mathrm{Sca}-1^{+} /\right.$lineage $\left.{ }^{-}\right)$. Hence, while colony-forming EPCs were significantly increased, definitive M2 macrophages (an increase of approximately fivefold) appeared after 5 days of this culture, and the ratio of $\mathrm{T}$ lymphocytes also increased to approximately twofold. These $\mathrm{T}$ lymphocytes were considered to support the anti-inflammatory phenotypes of cells, because
M2 macrophages were induced by the co-existence of these $\mathrm{T}$ lymphocytes, and IL-10 mRNA expression was significantly upregulated in E-MNCs. In fact, only the $\mathrm{CXCR}^{+}$/ $\mathrm{CXCR6}^{-}$Th2 cell fraction increased in $\mathrm{CD}^{+} / \mathrm{CD}^{+} \mathrm{T}$ helper cells after 5G-culture. In contrast, the expressions of proinflammatory genes such as IL- $1 \beta$ and IFN- $\gamma$ were largely downregulated. It has been reported that the M2 type of macrophages contributes to the inactivation of inflammation and fibrosis regression when an injury stabilizes $[34,35]$. Therefore, even with a cell number of approximately $1 \%$ of BMDC transplantation [6], those cell populations in E-MNCs may have been able to restore the atrophic glands. Moreover, several studies have shown the effectiveness of BMDC or cultured MSC therapies via local and systemic routes on the atrophic disease of the salivary glands $[6,8,9.12,14,15]$. Among these studies, Xu et al. have demonstrated the immunologic regulatory functions of umbilical cord MSCs play an important role in the amelioration of Sjögren's syndrome on both of basic studies and phase 1/2 clinical trials [36]. Considering such 
functional mechanisms of MSCs, effective cell populations in E-MNC may display the therapeutic functions through both of local and systemic injections for atrophic glandular diseases due to not only the radiation therapy but also Sjögren's syndrome.

With regard to the promotion of regenerative activities in the atrophic glands, transplanted E-MNCs must have functioned mostly in revascularization. Although the exact mechanisms by which they enhanced regeneration were not well elucidated in this study, the fact that microvascular endothelial cells in SGs are targets for radiation damage led us to this assumption [6,37]. 5Gculture of PBMNCs increased the number of colonyforming EPCs and M2 macrophages, which are known to play particularly important roles in vascularization by localizing themselves nearby newly forming blood vessels and aiding in their stabilization and fusion [24-26]. As noted in these prior works, EGFP-labeled donor EMNCs are detectable in portions of both the vascular endothelium and perivascular gland tissues at 2 weeks post-IR. In addition, $\mathrm{CD}^{+} \mathrm{T}$ lymphocytes, which are concentrated in E-MNCs with the anti-inflammatory phenotype, must be able to support the vasculogenic functions of EPCs and M2 macrophages because IL-10 and VEGF are produced by their interaction. Our in vivo data revealed elevated gene expression of VEGFs and their receptors accompanied by the downregulation of anti-inflammatory gene expressions in E-MNC-treated SGs at 4 weeks post-IR. In particular, VEGFR-3 (also known as Flt-4), which contributes to angiogenic sprouts [38], was significantly upregulated in treated SGs. VEGFR-3 is known to augment VEGF-induced angiogenesis and sustained angiogenesis even in the presence of VEGFR-2 (also known as Flk-1) inhibitors [39]. Moreover, Tammela et al. demonstrated that VEGFR-3 is strongly expressed in the angiogenic vessel front during the early postnatal period, but not in mature vessels [39]. Taking these data together, transplanted E-MNCs should have ameliorated chronic inflammation and subsequently at least induced revascularization. This led us to hypothesize that vasculogenic paracrine effects were accelerated forcefully by anti-inflammatory phenotypes of macrophages and T lymphocytes in E-MNCs. Indeed, we found that acinar and ductal cells clearly proliferated with less fibrosis in treated mice at 12 weeks. Then, the upregulation of AQP5 gene (a functional marker of SGs) in such specimens was also seen. Previous studies using modified or depleted macrophages have pointed to a role for them in inhibiting the fibrotic response [34, 40, 41]. On the other hand, it is known that the macrophage phenotype readily changes based on the spatiotemporal conditions at injured sites [26]. Therefore, transplantation of heterogenous cell fractions in E-MNCs, which are composed of M1 and M2 macrophages, lymphocytes in the anti-inflammatory phase, and endothelial stem/ progenitor cells, might have the advantage of being largely unaffected by undesirable host circumstances. At any rate, these vasculogenic and anti-inflammatory effects by E-MNCs may protect against fibrosis and then contribute to SG cell proliferation, even in severe radiogenic atrophic glands.

\section{Conclusions}

In conclusion, our results demonstrated that cell-based therapy using 5G-cultured PBMNCs can be effectively employed for radiation-induced salivary gland dysfunction without the need for complicated procedures [39]. This strategy can be easily applied in clinical settings, has low invasiveness, and uses a readily available source of cells. However, due to their vasculogenic properties, the transplantation of these cells may activate tumor proliferation, angiogenesis, or metastasis [42]. Therefore, the application of our current strategy should be restricted to patients with complete remission following radiation therapy for head and neck cancer. Further investigations are needed to understand the exact mechanisms of atrophic tissue restoration by transplanted E-MNCs and to determine the practical usefulness of this strategy for future clinical applications. Another limitation is that this study used a single-dose irradiation and may not correlate with current therapeutic regimens. Therefore, future investigation should be carried out by using additional clinical models such as fractionated-dose irradiation with chemotherapy. This study proposes that the serum-free 5G-culture system can make the peripheral blood a highly useful cell source for atrophic salivary gland regeneration.

\section{Supplementary information}

Supplementary information accompanies this paper at https://doi.org/10. 1186/s13287-019-1414-7.

\footnotetext{
Additional file 1. a Flow cytometric analysis of M2 macrophages (CCR2) Galectin $3^{+}$) in the $\mathrm{Pl}^{-} / \mathrm{CD}_{1} 1 \mathrm{~b}^{+}$cell fraction of PBMNCs (Day 0) and E-MNCs (Day 5). CCR2-/Galectin3 ${ }^{+}$cells occupied approximately $50 \%$ of the CD11b positive cell fraction in E-MNCs. High levels of intracellular galectin 3 expression are considered essential for transcriptional activation towards M2 macrophages after M1. b Flow cytometric analysis of T helper cells $\left(\mathrm{CD}^{+} / \mathrm{CD}^{+}\right)$in the PI fraction of PBMNCs (Day 0) and E-MNCs (Day 5). CXCR4 ${ }^{+} / \mathrm{CXCR6}^{-}$cells (Th2) were approximately 20\% of the CD3- and CD4-positive T helper cell fraction of E-MNCs. Th1, CXCR3 positive cells in T helper cells; Th17, CXCR4 and CXCR6 positive cells in T helper cells. c Representative pictures of EPC-CFU (Scale bar: $100 \mu \mathrm{m}$ ) at 7 days of EPC-CFA (100x), and the right panel shows ILB4-conjugated FITC binding and ACLDL-Dil uptake of each EPC-CFU (Scale bar: $100 \mu \mathrm{m})(40 \times)$. d Percentage of endothelial stem/progenitor cell fraction $\left({\mathrm{c}-\mathrm{Kit}^{+}}^{+}\right.$Sca- ${ }^{+} /$/ineage $\left.{ }^{-}\right)$in PBMNCs and E-MNCs.
}

Additional file 2. a Changes of salivary flow rate (SFR) in sham and PBMNCs groups at $0,4,8$, and 12 weeks after IR. b mRNA expressions of VEGFRs (flk1, flt-1, and flt4) at 4 weeks post-IR $\left({ }^{* *} p<0.01,{ }^{*} p<0.05\right)$.

Additional file 3. a Concentration of EGF in saliva at 8 weeks after IR. The saliva secreted from E-MNC-treated mice was increased in EGF when compared to non-transplanted mice $\left({ }^{*} p<0.05\right)$. b mRNA expressions of AQP5 at 12 weeks post-IR $\left({ }^{* *} p<0.01,{ }^{*} p<0.05\right)$. 


\section{Abbreviations}

AcLDL: Acetylated low-density lipoprotein; AQP5: Aquaporin 5 which is a water channel protein; BM: Bone marrow; BMDCs: Bone marrow-derived cells; BSA: Bovine serum albumin; CFA: Colony-forming assay; CFU: Colony-forming units; DAPI: 4',6-Diamidino-2'-phenylinodole;

EDTA: Ethylenediaminetetraacetic acid; EGF: Epidermal growth factor; EGFP: Enhanced green fluorescent protein; E-MNCs: Effectively conditioned PBMNCs; EPCs: Endothelial progenitor cells; Flk: Fetal liver kinase; Flt: Fmsrelated tyrosine kinase; H\&E: Hematoxylin and eosin; IFN- $\gamma$ : Interferon- $\gamma ;$ IL10: Interleukin-10; IL-1 $\beta$ : Interleukin- $\beta$; ILB4: Isolectin B4; IMDM: Iscove's modified Dulbecco's medium; IMRT: Intensity-modulated radiation therapy; IR: Irradiation; MSCs: Mesenchymal stem cells; PAS staining: Periodic acidSchiff staining; PB: Peripheral blood; PBMNCs: Peripheral blood mononuclear cells; PBS: Phosphate-buffered saline; PCNA: Proliferating cell nuclear antigen; PFA: Paraformaldehyde; PI: Propidium iodide; qPCR: Quantitative real-time polymerase chain reaction; QQ-culture: Quality and quantity-controlled culture; SFR: Salivary flow rate; SG: Salivary gland; TNF-a: Tumor necrosis factora; VEGF: Vascular endothelial growth factor; VEGFR: Vascular endothelial growth factor receptor

\section{Acknowledgements}

We thank Ms. Naomi Sakashita (Nagasaki University) and Dr. Mika Nishihara (CellAxia Inc.) for providing technical assistance with the experiments.

\section{Authors' contributions}

$\mathrm{TI}$ and YS contributed to the conception and design, financial support, collection and/or assembly of the data, data analysis and interpretation, and manuscript writing. TY, RH, IM, JR, TS, SK, and HM contributed to the collection and/or assembly of the data. MS and ST contributed to the conception and design. TA and IA contributed to the conception and design and supervision. All authors read and approved the final manuscript.

\section{Funding}

This work was supported by JSPS KAKENHI grant numbers 26893199 and 25670864 and AMED under grant number JP19bk0104069h0002.

\section{Availability of data and materials}

All data generated or analyzed during the current study are included in this published article.

\section{Ethics approval and consent to participate}

Animal care and experimental procedures were performed in accordance with the Guidelines for Animal Experimentation of Nagasaki University, with approval from the Ethics Committee for Animal Research (1605271307 and 1610051411).

\section{Consent for publication}

Not applicable.

\section{Competing interests}

The authors declare that they have no competing interests.

\section{Author details}

'Department of Regenerative Oral Surgery, Unit of Translational Medicine, Nagasaki University Graduate School of Biomedical Sciences, Nagasaki, Japan. ${ }^{2}$ Basic and Translational Research Center for Hard tissue Disease, Nagasaki University Graduate School of Biomedical Sciences, 1-7-1 Sakamoto, Nagasaki 852-8588, Japan. ${ }^{3}$ CellAxia Inc., Tokyo, Japan. ${ }^{4}$ Department of Applied Prosthodontics, Nagasaki University Graduate School of Biomedical Sciences, Nagasaki, Japan. ${ }^{5}$ Department of Regenerative Medicine Science, Tokai University School of Medicine, Isehara, Japan. ${ }^{6}$ Laboratory of Craniofacial Tissue Engineering and Stem Cells, Faculty of Dentistry, McGill University, Montreal, Canada

Received: 15 July 2019 Revised: 6 September 2019 Accepted: 10 September 2019 Published online: 17 October 2019

\section{References}

1. VissinK A, Burlaqe FR, Spijkervet FK, Jansma J, Coppes RP. Prevention and treatment of the consequences of head and neck radiotherapy. Crit Rev Oral Biol Med. 2003;14(3):213-25.
2. Tran SD, Sumita $Y$, Khalili S. Bone marrow-derived cells: a potential approach for the treatment of xerostomia. Int J Biochem Cell Biol. 2011;43(1):5-9.

3. Citrin D, Mansueti J, Likhacheva A, Sciuto L, Albert PS, Rudy SF, CooleyZgela T, Cotrim A, Solomon B, Colevas AD, Russo A, Morris JC, Herscher L, Smith S, Van Waes C. Long-term outcomes and toxicity of concurrent paclitaxel and radiotherapy for locally advanced head-and-neck cancer. Int J Radiat Oncol Biol Phys. 2009;74(4):1040-6.

4. Cnossen IC, van Uden-Kraan CF, Witte BI, Aalders YJ, de Goede CJ, de Bree R, Doornaert P, Rietveld DH, Buter J, Langendijk JA, Leemans CR, Verdonckde Leeuw IM. Prophylactic exercises among head and neck cancer patients during and after swallowing sparing intensity modulated radiation: adherence and exercise performance levels of a 12-week guided homebased program. Eur Arch Otorhinolaryngol. 2017;274(2):1129-38.

5. Baum BJ, Zheng C, Cotrim AP, McCullagh L, Goldsmith CM, Brahim JS, Atkinson JC, Turner RJ, Liu S, Nikolov N, Illei GG. Aquaporin-1 gene transfer to correct radiation-induced salivary hypofunction. Handb Exp Pharmacol. 2009;190:403-18.

6. Sumita Y, Liu Y, Khalili S, Maria OM, Xia D, Key S, Cotrim AP, Mezey E, Tran $\mathrm{SD}$. Bone marrow-derived cells rescue salivary gland function in mice with head and neck irradiation. Int J Biochem Cell Biol. 2011;43(1):80-7.

7. Ogawa M, Oshima M, Imamura A, Sekine Y, Ishida K, Yamashita K, Nakajima K, Hirayama M, Tachikawa T, Tsuji. Functional salivary gland regeneration by transplantation of a bioengineered organ germ. Nat Commun. 2013;4:2498.

8. Fang D, Shang S, Liu Y, Bakkar M, Sumita Y, Seuntjens J, Tran SD. Optimal timing and frequency of bone marrow soup therapy for functional restoration of salivary gland injured by single dose or fractionated irradiation. J Tissue Eng Regen Med. 2018;12(2):e1195-205.

9. Kojima T, Kanemaru S, Hirano S, Tateya I, Ohno S, Nakamura T, Ito J. Regeneration of radiation damaged salivary glands with adipose-derived stromal cells. Laryngoscope. 2011;121(9):1864-9.

10. Nanduri LS, Lombaert IM, van der Zwaag M, Faber H, Brunsting JF, van Os RP, Coppes RP. Salisphere derived c-Kit+ cell transplantation restores tissue homeostasis in irradiated salivary gland. Radiother Oncol. 2013;108(3):458-63.

11. Lombaert IM, Brunsting JF, Wierenga PK, Faber H, Stokman MA, Kok T, Visser WH, Kampinga HH, de Haan G, Coppes RP. Rescue of salivary gland function after stem cell transplantation in irradiated glands. PLoS One. 2008:3(4):e2063.

12. Khalili S, Faustman DL, Liu Y, Sumita Y, Blank D, Peterson A, Kodama S, Tran SD. Treatment for salivary gland hypofunction at both initial and advanced stages of Sjögren-like disease: a comparative study of bone marrow therapy versus spleen cell therapy with a 1-year monitoring period. Cytotherapy. 2014;16(3):412-23.

13. Tran SD, Liu Y, Xia D, Maria OM, Khalili S, Wang RW, Quan VH, Hu S, Seuntjens J. Paracrine effects of bone marrow soup restore organ function, regeneration, and repair in salivary glands damaged by irradiation. PLoS One. 2013;24;8(4):e61632.

14. An HY, Shin HS, Choi JS, Kim HJ, Lim JY, Kim YM. Adipose mesenchymal stem cell secretome modulated in hypoxia for remodeling of radiationinduced salivary gland damage. PLoS One. 2015;10(11):e0141862.

15. Yamamura $Y$, Yamada $H$, Sakurai T, Ide F, Inoue H, Muramatsu T, Mishima K, Hamada Y, Saito I. Treatment of salivary gland hypofunction by transplantation with dental pulp cells. Arch Oral Biol. 2013;58(8):935-42.

16. Asahara T, Murohara $T$, Sullivan A, Silver $M$, van der Zee $R, L i T$, Witzenbichler B, Schatteman G, Isner JM. Isolation of putative progenitor endothelial cells for angiogenesis. Science. 1997;275(5302):964-7.

17. Morris LM, Klanke CA, Lang SA, Pokall S, Maldonado AR, Vuletin JF, Alaee D, Keswani SG, Lim FY, Crombleholme TM. Characterization of endothelial progenitor cells mobilization following cutaneous wounding. Wound Repair Regen. 2010;18(4):383-90.

18. Zhao Z, Luo J, Ma L, Luo X, Huang L. Effect of granulocyte colony stimulating EPC on cardiac function and myocardial energy expenditure in patients with heart failure after myocardial infarction. Int J Clin Exp Med. 2015;15;8(9):16578-84.

19. Morancho A, Ma F, Barceló V, Giralt D, Montaner J, Rosell A. Impaired vascular remodeling after endothelial progenitor cell transplantation in MMP9-deficient mice suffering cortical cerebral ischemia. J Cereb Blood Flow Metab. 2015;35(10):1547-51.

20. Scheubel RJ, Zorn H, Silber RE, Kuss O, Morawietz H, Holtz J, Simm A. Agedependent depression in circulating endothelial progenitor cells in patients undergoing coronary artery bypass grafting. J Am Coll Cardiol. 2003;42:2073-80.

21. Masuda H, Iwasaki H, Kawamoto A, Akimaru H, Ishikawa M, li M, Shizuno T, Sato A, Ito R, Horii M, Ishida H, Kato S, Asahara T. Development of serumfree quality and quantity control culture of colony-forming endothelial progenitor cell for vasculogenesis. Stem Cells Transl Med. 2012;1(2):160-71. 
22. Tanaka R, Vaynrub M, Masuda H, Ito R, Kobori M, Miyasaka M, Mizuno H, Warren SM, Asahara T. Quality-control culture system restores diabetic endothelial progenitor cell vasculogenesis and accelerates wound closure. Diabetes. 2013;62(9):3207-17.

23. Masuda H, Tanaka R, Fujimura S, Ishikawa M, Akimaru H, Shizuno T, Sato A, Okada Y, lida Y, Itoh J, Itoh Y, Kamiguchi H, Kawamoto A, Asahara T. Vasculogenic conditioning of peripheral blood mononuclear cells promotes endothelial progenitor cell expansion and phenotype transition of antiinflammatory macrophage and T lymphocyte to cells with regenerative potential. J Am Heart Assoc. 2014;3(3):e000743.

24. Fantin A, Vieria JM, Gestri G, Denti I, Schwarz Q, Prykhozhij S, Peri F, Wilson SW, Ruhrberg C. Tissue macrophages act as cellular chaperones for vascular anastomosis downstream of VEGF-mediated endothelial tip cell induction. Blood. 2010;115(5):829-40.

25. Ogle ME, Segar CE, Sridhar S, Botchwey EA. Monocytes and macrophages in tissue repair: implications for immunoregenerative biomaterial design. Exp Biol Med. 2016;241(10):1084-97.

26. Krzyszczyk P, Schloss R, Palmer A, Berthiaume F. The role of macrophages in acute and chronic wound healing and interventions to promote pro-wound healing phenotypes. Front Physiol. 2018;1(9):419.

27. I T, Sumita Y, Minamizato T, Umebayashi M, Liu Y, Tran SD, Asahina I. Bone marrow-derived cell therapy for oral mucosal repair after irradiation. J Dent Res. 2014;93(8):813-20.

28. Shirakawa K, Endo J, Kataoka M, Katumata Y, Yoshida N, Yamamoto T, Isobe S, Moriyama H, Goto S, Kitakata H, Hiraide T, Fukuda K, Sano M. IL (interlukin)-10-STAT3-galectin-3 axis is essential for osteopontin-producing reparative macrophage polarization after myocardial infraction. Circulation. 2018;138(18):2021-35.

29. Agata H, Asahina I, Watanabe N, Ishii Y, Kubo N, Ohshima S, Yamazaki M, Tojo A, Kagami H. Characteristic change and loss of in vivo osteogenic abilities of human bone marrow stromal cells during passage. Tissue Eng Part A. 2010;16(2):663-73.

30. Xia D, Sumita Y, Liu Y, Tai Y, Wang J, Uehara M, Agata H, Kagami H, Fan Z, Asahina I, Wang S, Tran SD. GDFs promote tenogenic characteristics on human periodontal ligament-derived cells in culture at late passages. Growth Factors. 2013;31(5):165-73.

31. Kawasaki T, Sumita Y, Egashira K, Ohba S, Kagami H, Tran SD, Asahina I. Transient exposure to hypoxic and anoxic oxygen concentrations promotes either osteogenic or ligamentogenic characteristics of PDL cells. Biores Open Access. 2015;4(1):175-87.

32. Nemeth K, Leelahavanichkul A, Yuen P, Mayer B, Parmelee A, Doi K, Robey PG, Leelahavanichkul K, Koller BH, Brown JM, Hu X, Jelinek I, Star RA, Mezey E. Bone marrow stromal cells attenuate sepsis via prostaglandin E2dependent reprogramming of host macrophages to increase their interleukin-10 production. Nat Med. 2009;15(1):42-9.

33. Zhang QZ, Su WR, Shi SH, Wilder-Smith P, Xiang AP, Wong A, Nguyen AL, Kwon CW, Le AD. Human gingiva-derived mesenchymal stem cells elicit polarization of $\mathrm{m} 2$ macrophages and enhance cutaneous wound healing. Stem Cells. 2010;18(10):1856-68.

34. Duffield JS, Forbes SJ, Constandinou CM, Clay S. Partolina M, Vuthoori S, Wu S, Lang R, Iredale JP. Selective depletion of macrophages reveals distinct, opposing roles during liver injury and repair. J Clin Invest. 2005;115(1):56-65.

35. Watanabe $Y$, Tsuchiya A, Seino S, Kawata $Y$, Kojima $Y$, Ikarashi $S$, Lewis PJ, Lu WY, Kikuta J, Kawai H, Yamagiwa S, Forbes SJ, Ishii M, Terai S. Mesenchymal stem cells and induced bone marrow-derived macrophages synergistically improve liver fibrosis in mice. Stem Cells Transl Med. 2019;8(3):271-84.

36. Xu J, Wang D, Liu D, Fan Z, Zhang H, Liu O, Ding G, Gao R, Zhang C, Ding Y, Bromberg JS, Chen W, Sun L, Wand S. Allogenic mesenchymal stem cell treatment alleviates experimental and clinical Sjögren's syndrome. Blood. 2012;120(15):3142-51.

37. Choi JS, Park IS, Kim SK, Lim JY, Kim YM. Morphometric and functional changes of salivary gland dysfunction after radioactive iodine ablation in a murine model. Thyroid. 2013;23(11):1445-51.

38. Gerhardt $H$, Golding M, Fruttiger M, Ruhrberg C, Lundkvist A, abramsson A Jettsch M, Mitchell C, Alitalo K, Shima D, Betsholtz C. VEGF guides angiogenic sprouting utilizing endothelial tip cell filopodia. J Cell Biol. 2003;161:1163-77.

39. Tammela T, Zarkada G, Wallgard E, Murtomaki A, Suchting S, Wirzenius M, Waltari M, Hellstrom M, Schomber T, Peltonen R, Freitas C, Duate A, Isoniemi H, Laakkonen P, Christofori G, Yia-Herttuala S, Shibuya M, Pytowski B, Eichmann A, Betsholtz C, Alitalo K. Blocking VEGFR-3 suppresses angiogenic sprouting and vascular network formation. Nature. 2008;454(31):656-60.
40. Westerhuis R, van Straaten SC, van Dixhoom MG, van Rooijen N, Verhagen NA, Dijkstra CD, de Heer E, Daha MR. Distinctive roles of neutrophils and monocytes in anti-thy-1 nephritis. Am J Pathol. 2000;156:303-10.

41. Zhang-Hoover J, Sutton A, van Rooijen N, Sren-Streilein J. A critical role for alveolar macrophages in elicitation of pulmonary immune fibrosis. Immunology. 2000;101:501-11.

42. Ziebart T, Blatt S, Günther C, Völxen N, Pabst A, Sagheb K, Kühl S, Lambrecht T. Significance of endothelial progenitor cells (EPC) for tumorigenesis of head and neck squamous cell carcinoma (HNSCC): possible marker of tumor progression and neovascularization? Clin Oral Investig. 2016;20(8):2293-300.

\section{Publisher's Note}

Springer Nature remains neutral with regard to jurisdictional claims in published maps and institutional affiliations.
Ready to submit your research? Choose BMC and benefit from:

- fast, convenient online submission

- thorough peer review by experienced researchers in your field

- rapid publication on acceptance

- support for research data, including large and complex data types

- gold Open Access which fosters wider collaboration and increased citations

- maximum visibility for your research: over $100 \mathrm{M}$ website views per year

At $\mathrm{BMC}$, research is always in progress.

Learn more biomedcentral.com/submissions 